\title{
PENGARUH RELATED PARTY TRANSACTION DAN THIN CAPITALIZATION TERHADAP STRATEGI PENGHINDARAN PAJAK
}

\author{
SAPTA SETIA DARMA
}

Universitas Pamulang Tangerang Selatan

*Email : saptasdarma@gmail.com

\begin{abstract}
To determine the effect of related party transactions and thin capitalization on tax avoidance strategy is goals of this study. This research was conducted within the scope of manufacturing companies listed on the Indonesia Stock Exchange (BEI) that published their financial statements during the period 2012-2016 with using purposive sampling as sampling method. The analytical method used in this study are classic assumption test and multiple linear regression. Based on the test results it was found that the Related Party Transaction-Receivable, Related Party Transaction-Liability did not affect the effective tax rate. But the variables of thin capitalization, company size (size), and profitability affect the effective tax rate. This research is expected can be useful for management in decision making to tax avoidance strategies.
\end{abstract}

Keywords: related party transactions, liabilities, company size, profitability

\section{PENDAHULUAN}

\section{Latar Belakang Penelitian}

Penghindaran pajak (tax avoidance) adalah upaya menghindari pajak yang dilakukan dengan tetap mengindahkan ketentuan pajak yang berlaku namun dengan mengambil keuntungan dari celah-celah/kekurangan yang ada dalam peraturan perundang-undangan perpajakan yang berlaku (Pohan, 2013:23). Dan diantaranya dengan melakukan penentuan harga yang tidak wajar sehingga penghasilan atau beban yang dilaporkan adalah tidak sewajarnya (Handayani dan Arfan, 2014:13)

Perusahaan saat ini tidak hanya membatasi kegiatan usaha di negara sendiri, tetapi dalam menjalankan bisnisnya pelaku usaha juga melakukan ekspansi diluar negeri sehingga memungkinkan perusahaan untuk membuka anak perusahaan di luar negeri dan membentuk kelompok usaha (holding company) untuk mengkoordinasikan bisnis mereka agar mendapatkan sumber daya lebih. Hal ini akan menimbulkan berbagai transaksi antar anggota dalam kelompok usaha tersebut (baik barang berwujud, barang tidak berwujud, permodalan, dan sebagainya) melalui batas-batas negara melalui kegiatan transfer produk atau jasa 
(Belinda, 2016:1). Menurut Gusnardi (2009: 36-43), dalam kegiatan perusahaan tersebut mayoritas berupa transaksi diantara kelompok usaha mereka dan harga yang terjadi tidak mengacu pada harga pasar melainkan berdasarkan kebijakan harga transfer (transfer pricing) oleh holding company. Oleh karena itu dalam prakteknya Transfer pricing diartikan upaya yang dilakukan dengan cara menggeser harga atau laba antar perusahaan dalam satu kelompok usaha dengan maksud meminimalisir pajak (Kurniawan, 2014:1).

Menurut Gunadi dalam Belinda (2016:2), adanya Related Party Transaction atau transaksi pihak-pihak yang memiliki hubungan istimewa adalah sumber masalah yang ditimbulkan dari praktek transfer pricing. Dengan melakukan transaksi RPT sebagai strategi penghindaran pajak, maka dapat menghemat pajak yang harus dibayar perusahaan,sehingga dengan kondisi perusahaan di Indonesia yang rata-rata adalah perusahaan milik keluarga menjadikan RPT tersebut sebagai salah satu strategi penghindaran pajak yang banyak dilakukan.

Disisi lain dengan adanya fenomena penghindaran pajak dengan membuat komposisi utang jauh melebihi modal atau disebut dengan skema thin capitalization mendorong adanya praktik penyetoran modal terselubung dengan cara memberikan pinjaman yang melampaui batas kewajaran dengan pertimbangan adanya aturan bahwa bunga atas utang berbeda perlakuan perpajakannya dengan dividen atas investasi saham, sehingga bunga atas hutang dapat dikurangkan terhadap penghasilan kena pajak, sedangkan bunga atas modal tidak (Yuliati, 2016:5-6). Terkait modal dan hutang ini pemerintah telah mengaturnya dalam 169/PMK.010/2015.

\section{Rumusan Masalah}

1. Apakah strategi penghindaran pajak dipengaruhi oleh Related Party Transaction-Receivable (RPT-Piutang)

2. Apakah strategi penghindaran pajak dapat dipengaruhi Related Party Transaction-Liabilities (RPT-Hutang)

3. Apakah strategi penghindaran pajak dapat dipengaruhi Thin Capitalization

4. Apakah Related Party Transaction-Receivable (RPT-Piutang), Related Party Transaction-Liabilities (RPT-Hutang) dan Thin Capitalization berpengaruh terhadap Strategi Pengindaran Pajak

\section{Tujuan Penelitian}

1. Mendapatkan bukti empiris tentang besarnya pengaruh Related Party Transaction-Receivable (RPT-Piutang) terhadap Strategi Penghindaran Pajak

2. Mendapatkan bukti empiris tentang besarnya pengaruh Related Party Transaction-Liabilities(RPT-Hutang) terhadap Strategi Penghindaran Pajak

3. Mendapatkan bukti empiris tentang besarnya pengaruh Thin Capitalization terhadap Strategi Penghindaran Pajak

4. Mendapatkan bukti empiris tentang besarnya pengaruh Related Party Transaction-Receivable (RPT-Piutang), Related Party Transaction-Liabilities (RPT-Hutang), dan Thin Capitalization terhadap Strategi Penghindaran Pajak. 


\section{Kontribusi Penelitian}

Penelitian ini dapat memberi manfaat bagi manajemen perusahaan untuk manjadi bahan masukan atau salah satu faktor penting dalam pengambilan keputusan yang terkait dengan strategi penghindaran pajak.

\section{KERANGKA TEORITIS DAN PENGEMBANGAN HIPOTESIS}

\section{Related Party Transaction (RPT)}

Kontrak kerjasama antara agen atau manajer (yang diberikan wewenang) dengan prinsipal atau investor (yang memberi wewenang) merupakan bukti adanya hubungan kerja antar keduanya adalah prinsip dasar dari teori keagenan. Diantara agen dan prinsipal masing-masing ingin mendapatkan keuntungan yang sebesar-besarnya atau kepentingannya sesuai dengan informasi yang dimiliki yang dituangkan dalam kontrak kerja dan merupakan salah satu dari sekian banyak kontrak yang dimiliki perusahaan, dan hal ini menimbulkan perbedaan kepentingan yang menyebabkan konflik kepentingan antara pemilik modal dan manajer. Berdasarkan kontrak kerja yang disebutkan diatas para pemegang saham dan investor mempunyai hak untuk mendapatkan kesejahteraan secara maksimal yang harus diupayakan oleh manajer, sementara disisi lain manajer juga berkeinginan untuk mendapatkan kesejahteraannya yang sebesar-besarnya, dengan demikian akan terdapat penyatuan kepentingan dari pihak-pihak tersebut dan mengakibatkan timbulnya masalah-masalah yang disebut dengan masalah keagenan.

Dalam teori agensi dijelaskan bagaimana para manajer/agen dipacu untuk meningkatkan laba perusahaan dan mengatur agar dengan adanya beban pajak yang menyebabkan berkurangnya laba perusahaan tidak sampai berpengaruh terhadap kompensasi yang diterimanya sebagai penghargaan atas kinerjanya (Irawan dkk, 2017:406). Pengelolaan beban pajak seperti dimaksud yaitu dengan strategi penghindaran pajak dalam bentuknya berupa Related Party Transaction yang banyak dilakukan di Indonesia (Claessens dalam Belinda, 2:2016).

\section{Thin Capitalization}

Begitu juga dengan thin capitalization (cara penghindaran pajak dengan membuat komposisi utang jauh diatas modal) yang timbul dengan memanfaatkan adanya perbedaan perlakuan perpajakan bunga atas utang dengan dividen atas investasi saham, dan untuk melakukan cara ini dimungkin oleh perusahaan atau pihak-pihak yang ada hubungan dalam hal kepemilikan, kekeluargaan atau manajemen atau disebut memiliki hubungan istimewa yang dapat menjadi masalah dalam perpajakan, karena dengan cara memperbesar rasio hutang terhadap modal (debt to equity ratio) sebagai proksi dari thin capitalization hal ini mengindikasikan salah satu strategi penghindaran pajak dengan pemanfaatan beban bunga atas utang (Isgiyarta dalam Komariah, 28:2017). Menurut Diantari dan Ulupui (2016:27), seperti yang dijelaskan dalam teori keagenan bahwa untuk 
memaksimalkan kompensasi agen maka perusahaan menggunakan sumber daya yang dimilikinya dengan cara meminimalisir beban pajak perusahaan.

Terkait pihak-pihak yang memiliki hubungan istimewa sebagaimana disebutkan diatas telah diatur dalam Pernyataan Standar Akuntansi Keuangan (PSAK) Nomor 7 Paragraf ke-9 (Penyesuaian 2015) dan Undang-Undang Nomor 36 Tahun 2008 tentang Pajak Penghasilan.

\section{Strategi Penghindaran Pajak}

Penghindaran pajak merupakan tindakan yang tidak menyalahi ketentuan karena dilakukan dengan memanfaatkan ketentuan pajak yang ada, dan bisa diartikan segala tindakan dalam rangka meminimalisir beban pajak dengan menitikberatkan pada transaksi yang tidak termasuk objek pajak sebagai cara menghindari pajak, karena pada dasarnya pajak yang bisa dihindari itu tidak lain adalah yang tidak masuk dalam katagori objek pajak sebagaimana diatur dalam peraturan perpajakan. Chaniago (2013:6) mengutarakan strategi itu suatu proses yang meliputi penetapan rencana untuk jangka waktu tertentu dan cara mencapai tujuan tersebut melalui penggunaaan sumber daya secara efisien dan efektif. Oleh karena itu perusahaan dalam melaksanakan kebijakan penghindaran pajak diperlukan perencanaan yang baik yang dalam penyusunannya sudah memasukan atau mengikutsertakan semua sumber daya yang ada sehingga ketika masuk dalam tahap pelaksanaan kebijakan tersebut berjalan baik dan tujuan tercapai dengan hasil maksimal.

Salah satu strategi umum menghemat beban pajak adalah melalui perencanaan keuntungan atas subsidi pajak pada kondisi ketika suatu negara menerapkan tarif $\mathrm{PPh}$ yang lebih rendah maka perusahaan akan memindahkan operasi utamanya ke negara tersebut, salah satu cara yang dilakukan perusahaan untuk menghindari pajak yaitu dengan memindahkan subjek dan objek pajaknya ke negara yang memberlakukan ketentuan keringanan pajak (tax heaven country) Kurniasih dan Sari (2013:66)

\section{Penelitian Terdahulu}

Penelitian Oktavia, dkk (2012) menyebutkan adanya pengaruh negative pada tarif pajak efektif dari adanya transaksi hubungan istimewa menurut Standar Akuntansi Keuangan, dan juga dapat menjadi alternative sebagai pendeteksi keberadaan transaksi hubungan istimewa yang tidak semestinya.

Penelitian Belinda (2016) menyebutkan tidak terdapat pengaruh dengan adanya transaksi hubungan istimewa (penjualan dan pembelian) terhadap penghindaran pajak.

Ismi dan Linda (2016) menyebutkan thin capitalization, ROA secara bersama-sama (simultan) berpengaruh terhadap penghindaran pajak, namun secara parsial thin capitalization tidak berpengaruh terhadap penghindaran pajak.

Komariah (2017), menyebutkan thin capitalization pada perusahaan manufaktur di Indonesia tidak berpengaruh terhadap penghindaran pajak.

Penelitian Pea (2017), hasilnya menunjukan secara parsial tax avoidance dipengaruhi secara signifikan oleh ukuran perusahaan, dan secara simultan tax 
avoidance dipengaruhi secara signifikan oleh Ukuran perusahaan, leverage dan pertumbuhan penjualan

\section{Kerangka Berpikir Penelitian}

Penelitian tentang hubungan related party transaction, thin capitalization dengan strategi penghindaran pajak yang pernah dilakukan menyebutkan tidak adanya pengaruh RPT pada tax avoidance, sedangkan pada penelitian lainnya menunjukan adanya pengaruh thin capitalization terhadap penghindaran pajak. Sebagaimana sudah disampaikan diatas bahwa RPT dan thin capitalization merupakan tindakan yang pada akhirnya bertujuan dalam rangka mengefisiensikan beban pajak.

Dengan menggabungkan RPT dan thin capitalization, penelitian ini mengangkat masalah; apakah ada pengaruh RPT dan thin capitalization terhadap strategi penghindaran pajak baik secara parsial maupun simultan. Dalam mengangkat permasalahan tersebut, penulis memakai teori keagenan atau Agency Theory untuk menjelaskan RPT, thin capitalization dan strategi penghindaran pajak.

Variabel penelitian ini sesuai uraian diatas terdiri related party transaction, thin capitalization sebagai variabel bebas (variabel independen), ukuran perusahaan (size) dan profitabilitas (ROA) sebagai variabel kontrol, strategi penghindaran pajak sebagai variabel terikat (variabel dependen).

\section{Hipotesis Penelitian}

$\mathrm{H}_{1}$ : Related Party Transaction-Receivable (RPT-Piutang) berpengaruh terhadap Strategi Penghindaran Pajak

$\mathrm{H}_{2}$ : Related Party Transaction-Liability (RPT-Hutang) berpengaruh terhadap Strategi Penghindaran Pajak

$\mathrm{H}_{3}$ : Thin Capitalization berpengaruhterhadap strategi penghindaran pajak.

$\mathrm{H}_{4}$ : RPT-Piutang, RPT-Hutang, dan Thin Capitalization berpengaruh secara simultan terhadap strategi penghindaran pajak.

\section{Jenis Penelitian}

Sesuai dengan unsur-unsur yang ada dalam rancangan penelitian ini berikut data yang dipakai, maka jenis penelitian termasuk kuantitatif korelasional atau asosiatif yang melihat keterkaitan variabel bebas dengan variabel terikat.

\section{Lokasi Penelitian}

Sesuai data yang dipakai untuk penelitian ini, yaitu Bursa Efek Indonesia (BEI) Jakarta yang merupakan tempat bagi perusahaan manufaktur yang statusnya terdaftar sebagai perusahaan publik di Indonesia untuk periode 2012-2016. 


\section{METODE RISET}

\section{Populasi dan Sampel}

Dengan pertimbangan agar penelitian ini lebih bisa menggambarkan atau mewakili perusahaan-perusahaan yang terdaftar di BEI serta mencerminkan keadaan yang lebih mendekati kondisi sekarang maka populasi yang diambil adalah perusahaan manufaktur yang terdaftar (listed) untuk periode 2012-2016.

Teknik pengambilan sampel memakai purposive sampling, dengan pertimbangan atau kriteria-kriteria:

1. Perusahaan manufaktur terdaftar di BEI tahun 2012-2016

2. Laporan keuangan perusahaan manufaktur tahun 2012-2016 memiliki laba.

3. Laporan keuangan tahun 2012-2016 dalam mata uang rupiah

4. Laporan keuangan tahun 2012-2016 lengkap sesuai dengan variabel yang diperlukan

\section{Teknik Pengumpulan Data}

Setelah melalui rangkaian kegiatan seperti dijelaskan diatas, maka langkah berikutnya menentukan teknik pengumpulan data yang disesuaikan dengan jenis dan sifat penelitian, dalam penelitian ini memakai teknik analisis dokumen dengan melakukan analisis terhadap data sekunder laporan keuangan yang dimuat di IDX Statistic tahun 2012 sampai dengan 2016 melalui website www.idx.co.id, selain itu melakukan analisis jurnal, analisis buku dan analisis catatan historis sebagai pokok kajian (library research).

\section{Definisi Operasional Variable}

Variabel yang dipakai yaitu; Strategi Penghindaran Pajak (Effective Tax Rate) (Y), Related Party Transaction-Receivable (X1), Related Party Transaction-Liability (X2), Thin Capitalization (X3), Perusahaan (Size) dan Profitabilitas (ROA), dengan perincian sebagai berikut :

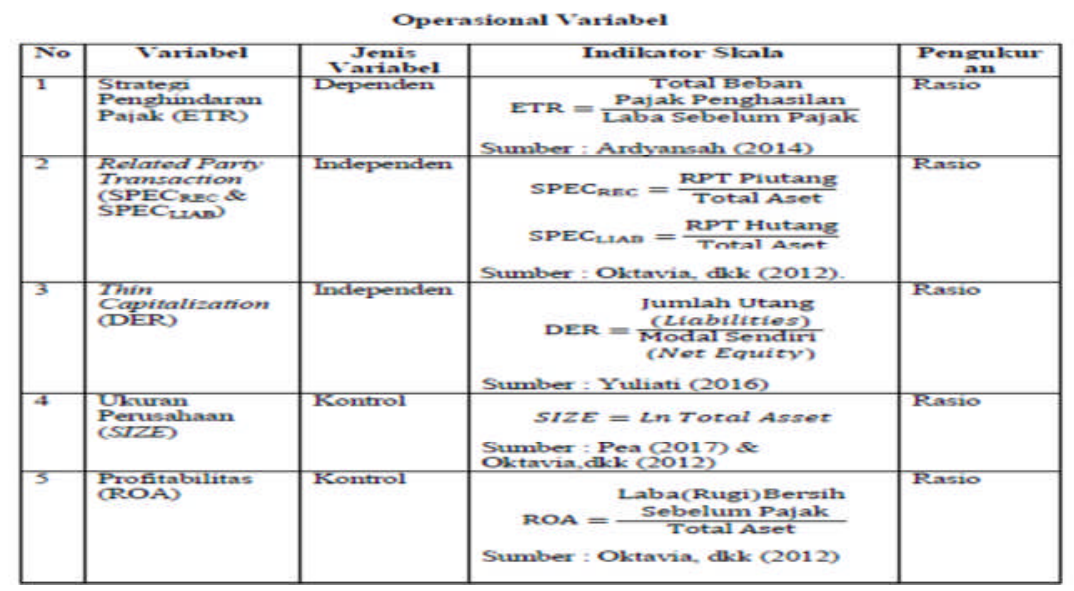




\section{Teknik Analisis Data}

Setelah rangkaian kegiatan seperti dijelaskan diatas dilalui, maka langkah berikutnya yang sangat menentukan ketepatan hasil penelitian adalah analisis data, dan sesuai dengan perumusan masalah, pemilihan sampel, perlakuan data sesuai dengan karakeristiknya dan skala pengukuran, maka teknik untuk menganalisis data terdiri Mean, Standard Deviasi, T Test, F Test, Anova, Multiples Correlation, Partial Correlation, Multiples Regression dengan menggunakan Statistical Product and Service Solution (SPSS) 22 for Windows karena memudahkan peneliti dalam menguji data sampel penelitian.

\section{Metode Analisis}

Menghitung sesuai pengukuran (rasio) yang ditetapkan kemudian dilakukan analisis statistik deskriptif, uji asumsi klasik dan uji hipotesis. Metode analisis dilakukan dengan bantuan SPSS.

\section{ANALISIS DATA}

Analisis data yang disajikan meliputi analisis deskriptif, validitas dan reliabilitas, uji asumsi klasik dan uji hipotesis dengan multipel regresi. Berikut ini tabel hasil pengujian statistik deskriptif yang telah diperoleh menggunakan SPSS 22 untuk mengetahui gambaran mengenai Pengaruh Related Party Transaction dan Thin Capitalization Terhadap Strategi Penghindaran Pajak sebagai berikut:

\begin{tabular}{|l|r|r|r|r|r|}
\hline & N & Minimum & Maximum & Mean & Std. Deviation \\
\hline RPT_REC & 125 & .00 & .26 & .0298 & .04928 \\
RPT LIAB & 125 & .00 & .11 & .0195 & .01933 \\
TC & 125 & .15 & 2.22 & .7648 & .49553 \\
SIZE & 125 & 26,24 & 33,20 & 29,0274 & 1,67935 \\
ROA & 125 & .00 & .41 & .1275 & .08133 \\
TAXAVOIDANCE & 125 & .07 & .53 & .2701 & .08043 \\
Valid N (listwise) & 125 & & & \\
Sumber: Hasil data sekunder SPSS versi 22 diolah oleh peneliti (2018)
\end{tabular}

Related Party Transaction Receivable (RPT_REC) nilai minimum sebesar 0,00 mengindikasikan selama periode penelitian ada Emiten yang tidak melakukan transaksi RPT_REC, nilai maksimum sebesar 0,26 mengindikasikan selama periode penelitian ada Emiten yang paling tinggi melakukan transaksi RPT_REC, nilai rata-rata (mean) sebesar 0,0298 hampir mendekati nilai tertinggi dibanding nilai terendah mengindikasikan selama periode penelitian lebih banyak RPT_REC mempengaruhi secara positif strategi penghindaran pajak, dan standar deviasi sebesar 0,04928 mengindkasikan nilai rata-rata berada diantara $+/-1$ dari nilai standar deviasi, dengan cakupan data penelitian kisaran 68\% dari 125 sampel.

Related Party Transaction-Liability (RPT_LIAB) nilai minimum sebesar 0,00 mengindikasikan selama periode penelitian ada Emiten (Argha Karya Prima industry Tbk) yang tidak melakukan transaksi RPT_LIAB, nilai maksimum 
sebesar 0,11 mengindikasikan selama periode penelitian ada Emiten (Japfa Comfeed Indonesia Tbk.) yang paling tinggi melakukan transaksi RPT_LIAB, nilai rata-rata (mean) sebesar 0,0195 hampir mendekati nilai tertinggi dibanding nilai terendah mengindikasikan selama periode penelitian lebih banyak RPT_LIAB mempengaruhi secara positif strategi penghindaran pajak, dan standar deviasi sebesar 0,01933, mengindkasikan nilai rata-rata berada diantara $+/-1$ dari nilai standar deviasi, dengan cakupan data penelitian kisaran $68 \%$ dari 125 sampel.

Thin Capitalization nilai minimum sebesar 0,15 mengindikasikan selama periode penelitian ada Emiten (Delta Djakarta Tbk) yang melakukan transaksi Thin Capitalization paling rendah, nilai maksimum sebesar 2,22 mengindikasikan selama periode penelitian ada Emiten (Aneka Gas Industri Tbk) yang paling tinggi melakukan transaksi Thin Capitalization, nilai rata-rata (mean) sebesar 0,7648 hampir mendekati nilai terendah dibanding nilai tertinggi mengindikasikan selama periode penelitian lebih banyak Thin Capitalization tidak mempengaruhi strategi penghindaran pajak, dan standar deviasi sebesar 0,49553 mengindkasikan nilai rata-rata berada diantara +/-1 dari nilai standar deviasi, dengan cakupan data penelitian kisaran $68 \%$ dari 125 sampel.

Strategi Penghindaran Pajak (Tax Avoidance) nilai minimum sebesar 0,07 mengindikasikan selama periode penelitian ada Emiten (Indocement Tunggal Perkasa Tbk) yang melakukan transaksi Tax Avoidance paling rendah, nilai maksimum sebesar 0,53 mengindikasikan selama periode penelitian ada Emiten (Indospring Tbk) yang paling tinggi melakukan transaksi Tax Avoidance, nilai rata-rata (mean) sebesar 0,2701 hampir mendekati nilai terendah dibanding nilai tertinggi mengindikasikan selama periode penelitian lebih banyak Emiten yang melakukan Tax Avoidance yang rendah, dan standar deviasi sebesar 0,08043, mengindkasikan nilai rata-rata berada diantara $+/-1$ dari nilai standar deviasi, dengan cakupan data penelitian kisaran 68\% dari 125 sampel.

Ukuran Perusahaan (Size) nilai minimum sebesar 26,24 mengindikasikan selama periode penelitian Emiten yang mempunyai size paling rendah sebesar 26,24, nilai maksimum sebesar 33,20 mengindikasikan selama periode penelitian Emiten yang memiliki size paling tinggi sebesar 33,20, nilai rata-rata (mean) sebesar 29,0274 hampir mendekati nilai terendah dibanding nilai tertinggi mengindikasikan selama periode penelitian lebih banyak ukuran perusahaan Emiten tidak mempengaruhi Tax Avoidance, dan standar deviasi sebesar 1,67935 mengindkasikan nilai rata-rata berada diantara $+/-1$ dari nilai standar deviasi, dengan cakupan data penelitian kisaran $68 \%$ dari 125 sampel.

Profitabilitas (ROA) nilai minimum sebesar 00,00 mengindikasikan selama periode penelitian Emiten yang mempunyai ROA paling rendah sebesar 00,00, nilai maksimum sebesar 00,41 mengindikasikan selama periode penelitian Emiten yang memiliki ROA paling tinggi sebesar 00,41, nilai rata-rata (mean) sebesar 12,75 hampir mendekati nilai terendah dibanding nilai tertinggi mengindikasikan selama periode penelitian lebih banyak ROA Emiten tidak mempengaruhi Tax Avoidance, dan standar deviasi sebesar 1,67935 mengindkasikan nilai rata-rata berada diantara +/-1 dari nilai standar deviasi, dengan cakupan data penelitian kisaran 68\% dari 125 sampel. 


\section{Gambaran Umum Objek Penelitian}

Perusahaan manufaktur menempati jumlah terbanyak di Bursa Efek Indonesia (BEI) dengan hampir $40 \%$ nya dari total perusahaan yang terdaftar di BEI, disamping itu jenis perusahaan ini karena sifatnya mengutama proses produksi dari barang mentah menjadi barang jadi berakibat banyaknya transaksi pembelian ataupun penjualan yang terjadi yang berujung pada timbulnya hutang dan piutang (termasuk RPT).

\section{Pengujian Asumsi Klasik}

\section{Uji Normalitas}

Menurut Ghozali (2016:154) uji normalitas dilakukan agar bisa diketahui kemungkinan ditemukannya model regresi, variabel pengganggu atau residual memiliki distribusi tidak normal yang bisa diketahui melalui analisa grafik atau analisa non parametik Kolmogorov-Smirnov (K-S).

1) Analisis Grafik

Berdasarkan grafik bila data menyebar sekitar dan sesuai arah garis diagonal atau pola histogram berdistribusi normal berarti model regresi dapat dikatakan normal

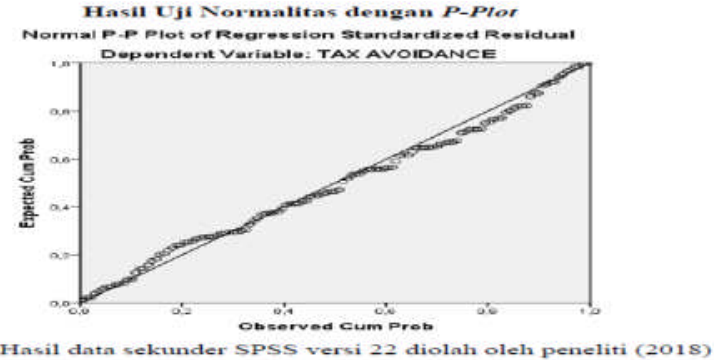

2) Analisis Statistik

Dengan Uji Kolmogorov-Smirnov (K-S) dilakukan dengan ketentuan bila nilai nilai signifikansi atau nilai probabilitas $>0,05$, maka distribusi dikatakan normal (Ghozali, 2013:163)

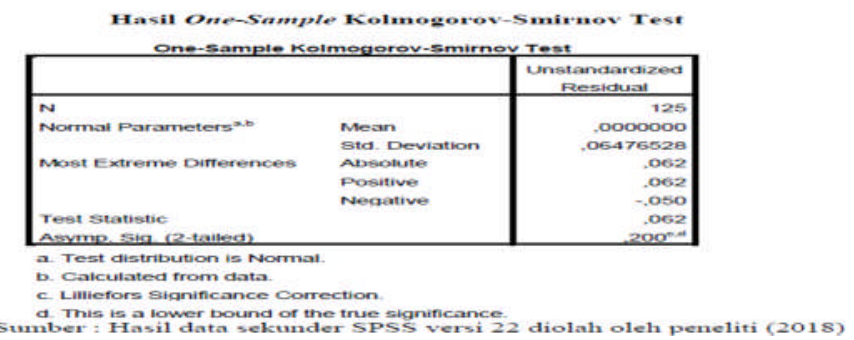

Dari gambar diatas nilai Asymp.Sig.(2-tailed) 0,200>0,05 yang berarti model regresi dapat dikatakan normal 
2. Uji Multikolinearitas

Adanya kemiripan yang bisa menimbulkan korelasi antar 1 variabel independen dengan variabel independen lainnya dalam satu model regresi bisa menimbulkan multikolonieritas, dan jika terjadi maka harus dibuang salah satu variabel independennya, namun untuk mengetahui ada tidak nya multikolonieritas harus dilakukan dengan menganalisa matrik korelasi diantara variabel bebas dan menghitung nilai Tolerance, variance inflation factor (VIF) yang bila $\mathrm{VIF}<10$ atau nilai tolerance $>0,10$ berarti tidak terjadi multikolonieritas Ghozali (2013:105).

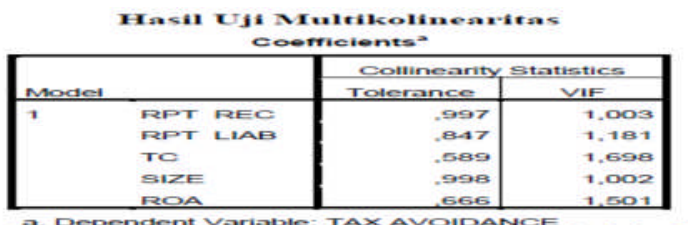

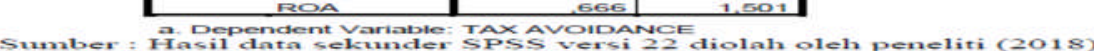

Berdasarkan tabel diatas mengindikasikan nilai tolerance variabel Related Party Transaction Receivable (RPT_REC), Related Party Transaction Liabilities (RPT_LIAB), Thin Capitalization (TC), Ukuran Perusahaan (SIZE), Profitabilitas (ROA) berkisar antara 0,589 sampai 0,998 atau >0,10.

3. Uji Autokorelasi

Suatu model regresi yang baik adalah yang tidak mengalami masalah autokorelasi, problem ini terjadi karena antar satu pengamatan/periode satu sama lain terjadi korelasi yang biasanya terjadi pada data yang berurut (time series). Dan untuk mengatasinya dilakukan uji uji Durbin Watson (DW) dengan ketentuan jika nilai DW berada diantara -2 dan +2 , tidak terjadi autokorelasi (Sunyoto, 2007:105)

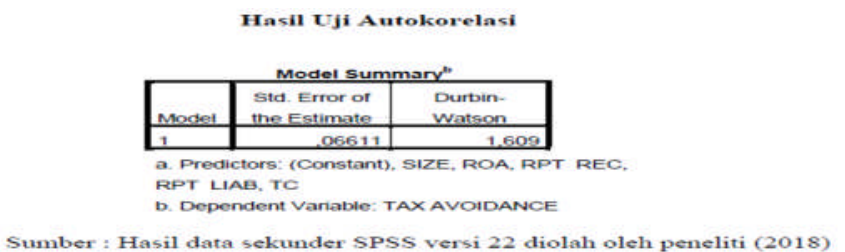

Berdasarkan gambar diatas nilai $D W 1,609$ yang berarti diantara -2 dan $+2(-2 \leq$ $\mathrm{DW} \leq+2)$.

4. Uji Heteroskedastisitas

Terjadinya kondisi variance dari satu residual suatu pengamatan yang satu sama lain tersifat tetap (homoskedastisitas) merupakan indikasi bahwa model regresi yang baik dalam arti bahwa tidak terjadi heteroskedastisitas (terjadi perbedaan variance residual pada satu pengamatan dengan 
pengamatan lainnya). Dan untuk memastikan tidak terjadi perbedaan variance tersebut dilihat pada grafik scatter plot yang apabila dalam grafik tersebut menunjukan pola yang tidak beraturan dan penyebaran titik-titik terjadi diatas dan dibawah angka 0 (sumbu Y) maka dikatakan tidak terjadi perbedaan variance atau heteroskedastisitas (Ghozali 2013:140).

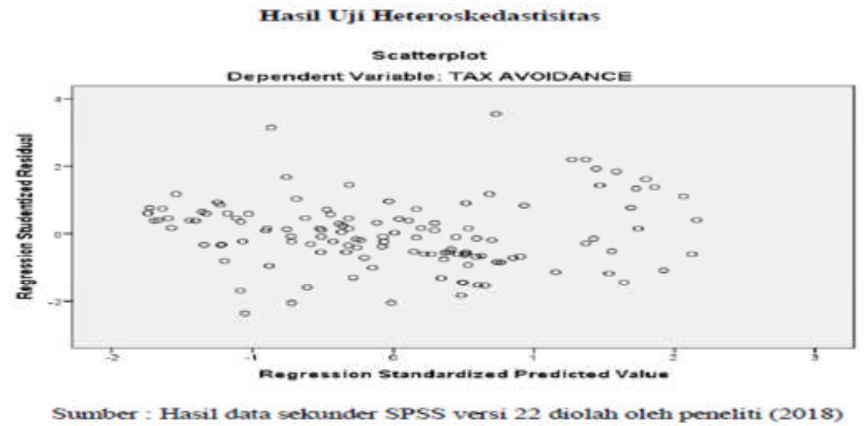

Berdasarkan grafik scatterplot diatas dalam model regresi ini tidak terjadi heteroskedastisitas

\section{Uji Statistik \\ Uji Koefisien Determinasi $\left(\mathbf{R}^{2}\right)$}

Regresi merupakan ketergantungan variabel terikat pada variabel bebas dengan begitu dapat diketahui rata-rata populasi/variabel terikat berdasarkan nlai variabel bebas yang ada. Dan untuk itu perlu dilakukan analisis regresi yang nantinya menghasilkan koefisien masing-masing variabel bebas yang diperoleh melalui prediksi nilai variabel terikat dengan suatu persamaan sehingga dari koefisien ini bertujuan untuk meminimalkan penyimpangan nilai aktual dari nilai estimasi variabel terikat-nya.

Suatu fungsi regresi yang baik adalah diukur dari ketepatan dalam menaksir nilai aktual yang diukur salah satunya dengan nilai koefisien determinasi $\left(R^{2}\right)$ yang berkisar antara nol dan satu. Sehingga bila nilai $R^{2}$ mendekati satu berarti variabel independen mampu menyediakan hampir semua informasi yang dibutuhkan untuk memprediksi variasi variabel terikat. Namun sifat dari $\mathrm{R}^{2}$ ini adalah bias terhadap jumlah variabel bebas yang dimasukan kedalam model regresi karena ketika satu variabel bebas bertambah maka $R^{2}$ pun bertambah tanpa memperhitungkan variabel tersebut berpengaruh terhadap variabel terikat, dan untuk mengatasi kondisi ini maka peneliti dianjurkan untuk memakai nilai Adjusted $\mathrm{R}^{2}$ yang bersifat lebih fleksibel. 


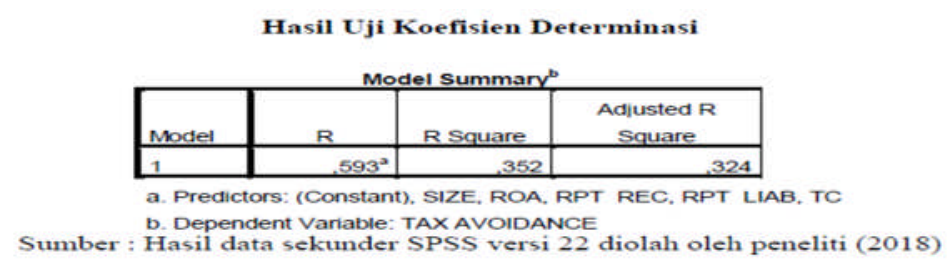

Dalam gambar diatas, nilai Adjusted R square 0,324 yang berarti 32,4\% variasi Strategi Penghindaran Pajak dapat dijelaskan oleh variasi variabel Related Party Transaction Receivable (RPT-REC), Related Party Transaction Liabilitas (RPT-LIAB), Thin Capitalization (TC), Size dan ROA dan sisanya sebesar $(100 \%-32,4 \%=67,6 \%)$ dijelaskan sebab-sebab lain diluar model regresi ini.

\section{Uji Statistik t (Parsial)}

Suatu fungsi regresi yang baik adalah diukur dari ketepatan untuk memperkirakan nilai aktual yang ditentukan melalui nilai statistik t dengan uji $t$ (parsial) karena uji ini bertujuan mengukur tingkat pengaruh variabel bebas terhadap variabel terikat secara parsial melalui perbandingan nilai t tabel dan $t$ hitung dan juga harus diperhatikan apakah sig t lebih besar atau lebih kecil dari sig 0,05 .

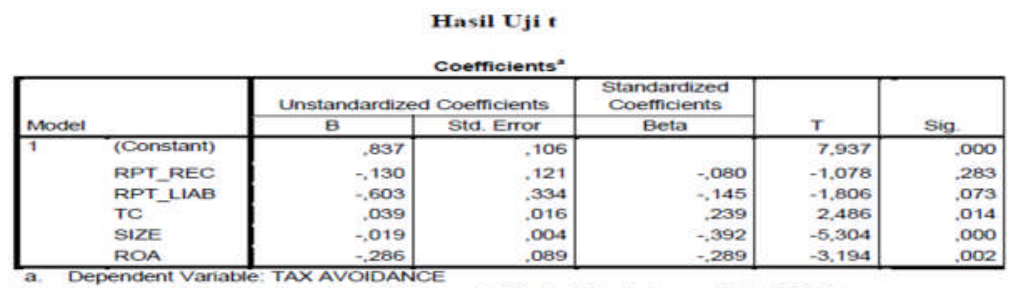

Sumber : Hasil data sekunder SPSS versi 22 diolah oleh peneliti (2018)

Dalam gambar terlihat nilai t tabel 1,98010 dapat dicari tabel statistik pada signifikansi 0,05/2 $=0,025$ dengan degree of freedom $(\mathrm{df})=\mathrm{n}-\mathrm{k}-1(125-5-1$ $=119)$ untuk jumlah sampel $(n)=125$.

Berdasarkan gambar diatas dilakukan pengujian hipotesis secara parsial (uji t) variabel sebagai berikut:

1) Variabel Related Party Transaction-Receivable (RPT_REC) t hitung 1,078 dan sig 0,283 , dan $\mathrm{t}$ tabel 1,98010 dengan nilai sig 0,05 ini berarti $\mathrm{t}$ hitung $<\mathrm{t}$ tabel yaitu $1,078<1,98010$. Selanjutnya nilai sig $0,283 \geq$ 0,05,makarelated party transaction-receivable tidak berpengaruh terhadap strategi penghindaran pajak atau H1 ditolak.

2) Variabel Related Party Transaction-Liabilities (RPT_LIAB) t hitung 1,806 dan sig 0,073 , serta $t$ tabel 1,98010 dengan sig 0,05 ini berarti $t$ hitung $<\mathrm{t}$ tabel yaitu $1,806<1,98010$. Selanjutnya nilai sig $0,073 \geq$ 
0,05,makarelated party transaction-liability tidak berpengaruh terhadap strategi penghindaran pajak atau H2ditolak.

3) Hasil uji t untuk variabel Thin Capitalization (TC) t hitung sebesar 2,486 dan sig 0,014, serta t tabel 1,98010 dengan sig 0,05 ini berarti $t$ hitung $>t$ tabel yaitu $2,486>1,98010$. Selanjutnya nilai sig $0,014 \leq 0,05$, maka thin capitalization berpengaruh terhadap strategi penghindaran pajak atau $\mathrm{H}_{3}$ diterima.

\section{Uji Statistik F (Simultan)}

Suatu fungsi regresi yang baik adalah diukur dari ketepatan dalam menaksir nilai aktual yang diukur salah satunya dengan nilai statistik $\mathrm{F}$ yang diperoleh melalui uji statistik F, yaitu untuk mendeteksi apakah semua variabel bebas secara bersama-sama berpengaruh terhadap variabel terikat dengan tingkat signifikansi yang dipakai 0,05 dan ketentuannhya adalah untuk nilai signifikan $\leq 0,05$ atau $F$ hitung > F tabel maka dikatakan terjadi pengaruh secara simultan.

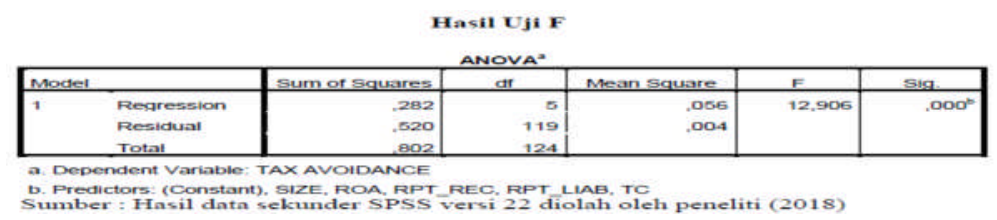

Berdasarkan gambar diatas, nilai F-hitung sebesar 12,906 dan F-tabel diperoleh dengan taraf signifikansi $\alpha=0,05$, dengan degree of freedom $(\mathrm{df})=(\mathrm{k}$; $\mathrm{n}-\mathrm{k})$, jadi $\mathrm{F}(5 ; 120)$ ini berarti $\mathrm{F}$ hitung $>\mathrm{F}$ tabel yaitu $12,906>2,29$ dengan sig $0,000 \leq 0,050$, maka secara simultan seluruh variabel Related Party Transaction dan Thin Capitalization berpengaruh terhadap strategi penghindaran pajak

\section{Analisis Regresi Linier Berganda}

Untuk meneliti variabel bebas yang berpengaruh terhadap variabel terikat digunakan model analisis berupa model regresi berganda.
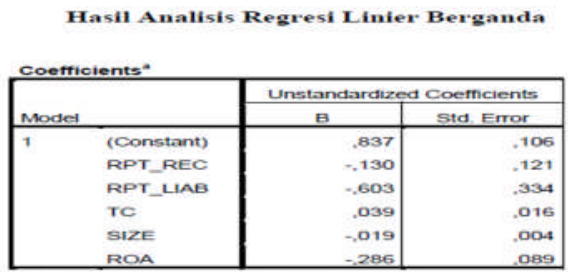

a. Dependent Variable: TAX AVOIDANCE
Sumber : Hasil data sekunder SPSS versi 22 diolah oleh peneliti (2018)

Berdasarkan gambar diatas menunjukan nilai koefisien dari persamaan regresi, sehingga didapatkan persamaan :

$\mathrm{Y}=\mathrm{a}+\beta 1 \mathrm{X} 1+\beta 2 \mathrm{X} 2+\beta 3 \mathrm{X} 3+\beta 4 \mathrm{X} 4+\beta 5 \mathrm{X} 5+\mathrm{e}$

$\mathrm{Y}=0,837-0,130 \mathrm{X} 1-0,603 \mathrm{X} 2+0,039-0,019 \mathrm{X} 4-0,286+\mathrm{e}$

1. Konstanta sebesar 0,837 
Jika diasumsikan nilai dari variabel independen adalah konstan (0 atau tidak ada), maka nilai variabel dependen yaitu variabel Strategi Penghindaran Pajak (tax avoidance) akan meningkat sebesar 0,837.

2. Koefisien $=-0,130$

Variabel Related Party Transaction-Receivable (RPT_REC) dengan koefisien -0,130, artinya peningkatan variabel Related Party Transaction-Receivable (RPT_REC) sebesar satu satuan maka Strategi Penghindaran Pajak (tax avoidance) akan mengalami penurunan sebesar $-0,130$.

3. Koefisien $=-0,603$

Variabel Related Party Transaction-Liabilities (RPT_LIAB) dengan koefisien -0,603, artinya peningkatan variabel Related Party TransactionLiabilities(RPT_LIAB) sebesar satu satuan maka Strategi Penghindaran Pajak (tax avoidance) akan mengalami penurunan sebesar -0,603.

4. Koefisien $=0,039$

Variabel Thin Capitalization (TC) koefisiennya 0,039, artinya peningkatan variabel Thin Capitalization (TC) sebesar satu satuan maka Strategi Penghindaran Pajak (tax avoidance) akan mengalami peningkatan sebesar 0,039 .

5. Koefisien $=-0,019$

Variabel ukuran perusahaan(Size) koefisiennya $-0,019$, artinya peningkatan variabel ukuran perusahaan(Size) sebesar satu satuan maka Strategi Penghindaran Pajak (tax avoidance) akan mengalami penurunan sebesar 0,019 .

6. Koefisien $=-0,286$

Variabel profitabilitas(ROA) koefisiennya -0,286, artinya peningkatan variabel profitabilitas(ROA) sebesar satu satuan maka Strategi Penghindaran Pajak (tax avoidance) akan mengalami penurunan sebesar -0,286.

\section{Pembahasan}

Berdasarkan hasil olah data maka dapat diperoleh data bahwa Variable

Related Party Transaction-Receivable (RPT_REC) tidak berpengaruh terhadap Strategi Penghindaran Pajak terbukti nilai $t$ hitung lebih kecil dari pada t tabel yaitu $1,078<1,98010$. Selanjutnya nilai sig $0,283 \geq 0,05$, maka related party transaction-receivable tidak berpengaruh terhadap strategi penghindaran pajak atau $\mathrm{H}_{1}$ ditolak dan ini sesuai penelitian yang dilakukan oleh Djari (2016) mengungkapkan bahwa perusahaan yang mempunyai piutang dengan pihak berelasi sengaja mengadakan perjanjian dengan pihak terkait hingga tidak terdapat lagi piutang dengan pihak berelasi.

Variable Related Party Transaction-Liabilities (RPT_LIAB) tidak berpengaruh terhadap Strategi Penghindaran Pajak terbukti nilai $t$ hitung lebih kecil daripada $t$ table yaitu $1,806<1,98010$ dengan sig $0,073 \geq 0,05$, maka related party transaction-liability tidak berpengaruh terhadap strategi penghindaran pajak atau $\mathrm{H}_{2}$ ditolak dan ini sesuai penelitian yang dilakukan oleh Djari (2016) mengungkapkan bahwa hal ini sama seperti piutang hubungan istimewa, hutang hubungan istimewa tidak ada pengaruhnya pada tarif pajak efektif karena adanya pemberian jasa atau perjanjian kerjasama timbal balik antara pihak berelasi 
sehingga hutang dengan pihak berelasi tidak berpengaruh terhadap tarif pajak efektif perusahaan.

Variabel Thin Capitalization berpengaruh terhadap Strategi Penghindaran Pajak terbukti nilai t hitung lebih besar dari pada t tabelyaitu2,486 >1,98010 dengan sig $0,014 \leq 0,05$, makathin capitalization berpengaruh terhadap strategi penghindaran pajakatau $\mathrm{H}_{3}$ diterima dan ini sesuai penelitian yang dilakukan oleh Djari (2016) mengungkapkan dalam variabel leverage nya yang berpengaruh signifikan dengan arah positif menunjukkan bahwa semakin tinggi tingkat hutang yang dimiliki perusahaan maka semakin tinggi pula beban pajak yang dibayar, hal ini karena perusahaan menggunakan hutang untuk keperluan investasi danakan mendapatkan penghasilan lain diluar usaha yang membuat beban pajak yang dibayar bertambah.

Variabel Related Party Transaction dan Thin Capitalization sekaligus berpengaruh terhadap Strategi Penghindaran Pajak terbukti nilai F hitung lebih besar dari pada $F$ tabel yaitu12,906 > 2,29 dengan sig $0,000 \leq 0,050$ maka $\mathrm{H}_{4}$ diterima. Hasil penelitian ini sejalan dengan Yuliawati (2016) dan Oktavia, dkk (2012). Oleh karena itu diduga kuat bahwa dampak adanya transaksi hubungan istimewa di perusahaan menyebabkan kerugian pada penerimaan negara dari pajak dan hal ini terbukti dengan menurunnya beban pajak yang dibayar oleh perusahaan dan inilah sebabnya Related Party Transaction dan Thin Capitalization secara menyeluruh memiliki pengaruh terhadap Strategi Penghindaran Pajak.

\section{KESIMPULAN DAN SARAN}

\section{Kesimpulan}

1. Related Party Transaction-Receivable(RPT-Piutang) secara signifikan tidak memiliki pengaruh pada Strategi Penghindaran Pajak, sehingga $\mathrm{H}_{1}$ ditolak.

2. Related Party Transaction-Liabilities (RPT-Hutang) secara signifikan tidak memiliki pengaruh pada Strategi Penghindaran Pajak, sehingga $\mathrm{H}_{2}$ ditolak.

3. Thin Capitalization berpengaruh signifikan terhadap Strategi Penghindaran Pajak, sehingga $\mathrm{H}_{3}$ diterima.

4. Related Party Transaction-Receivable (RPT-Piutang), Related Party Transaction-Liabilities (RPT-Hutang), dan Thin Capitalization bersama-sama (simultan) secara signifikan memiliki pengaruh pada Strategi Penghindaran Pajak, sehingga $\mathrm{H}_{4}$ diterima.

\section{Saran}

1. Dengan terbuktinya bahwa kebijakan perusahaan dalam penghindaran pajak sangat terkait dengan adanya transaksi hubungan istimewa baik melalui penjualan barang atau jasa maupun melalui transaksi yang terkait bunga dan modal maka otoritas pajak seharusnya terus memperbaiki dan menegaskan lagi ketentuan yang mengatur perihal ini sehingga kemungkinan memanfaatkan kelemahan atau celah yang ada dalam ketentuan perpajakan oleh perusahaan dapat diminimalkan. Dengan demikian praktek 
penghindaran pajak dikalangan perusahaan yang beraktifitas di Indonesia yang merugikan bagi penerimaan APBN negara yang bersumber dari penerimaan pajak dapat diminimalisir.

2. Untuk penelitian selanjutnya diharapkan periode yang akan diteliti bisa lebih panjang serta untuk variabel bisa ditambahkan agar dapat memperoleh hasil yang lebih luas mengenai praktek penghindaran pajak dikalangan perusahaan-perusahaan yang ada di Indonesia.

\section{DAFTAR PUSTAKA}

Annisa. (2017). Pengaruh Return On Asset, Leverage, Ukuran Perusahaan dan Koneksi Politik Terhadap Penghindaran Pajak. JOM Fekon, Vol. 4 No. 1

Ardyansah, Danis. (2014). Pengaruh Size, Leverage, Profitability, Capital Intensity Ratio dan Komisaris Independen Terhadap Effective Tax Rate (ETR). Skripsi, Fakultas Ekonomi dan Bisnis Universitas Diponegoro : Semarang.

Belinda, Clarissa. (2016). Pengaruh Transaksi Hubungan Istimewa Sebagai Strategi Penghindaran Pajak Pada Perusahaan Manufaktur Di Bursa Efek Indonesia Tahun 2011-2014. Skripsi, Fakultas Bisnis Universitas Katolik Widya Mandala : Surabaya.

Chaniago, Syukri. (2013). Strategi Humas Universitas Lampung dalam Menarik Calon Mahasiswa Baru. Universitas Lampung.

Djari, Stefanny. (2016). Pengaruh Transaksi Hubungan Istimewa Terhadap Tarif Pajak Efektif Pada Perusahaan Pertambangan Di BEI Tahun 2010-2014, Skripsi. Fakultas Bisnis Universitas Katolik Widya Mandala : Surabaya.

Dyreng, Scott D., dkk. (2008). Long-Run Corporate Tax Avoidance,The Accounting Review 83 (1): 61-82.

Ghozali, Imam. (2013). Aplikasi Analisis Multivariate dengan program SPSS. Edisi ke 7 (Tujuh), Universitas Diponegoro : Semarang.

Gunadi. (2013). Pajak International. Salemba Empat.

Gusnardi. (2009). Penetapan Harga Transfer Dalam Kajian Perpajakan, Jurnal Pendidikan, ekonomi dan bisnis, Vol. 1 No. 1: 36-43.

Handayani, Desi dan Arfan, Tobi. (2014). Pengaruh Transaksi Perusahaan Afiliasi Terhadap Tarif Pajak Efektif. Jurnal Akuntansi Keuangan dan Bisnis Vol. 7 11-19.

Ikatan Akuntansi Indonesia (IAI). (2015). Pernyataan Standar Akuntansi Keuangan penyesuaian 2015. Nomor 7 Paragraf 9.Jakarta : Salemba Empat.

Ismi, Fadhil dan Linda., 2016. Pengaruh Thin Capitalization, Return on Asset,dan Corporate Governance pada Perusahaan Jakarta Islami Index (JII). JIMEKA. Vol. 1, No. 1. Hal 150-165.

Kuncoro, Mudrajad. (2013). Metode Riset untuk Bisnis \& Ekonomi. Jakarta : Erlangga ,Jakarta.

Kurniasih, Tommy., Sari., M. (2013). Pengaruh return On Asset, Leverage, Corporate Gevernence, Ukuran PerusahaanDan Kompensasi Rugi Fiskal 
Pada Tax Avoidance. Jurnal Akuntansi Udayana. Vol.18, No.1, Februari: 58-66.

Kurniawan, A.M. (2011). Pajak Internasional beserta Contoh Aplikasinya. Jakarta : Ghalia Indonesia.

Komariah, Nurul. (2017). Pengaruh Thin Capitalization dan Karakter Eksekutif dengan Kompensasi Manajemen Kunci Sebagai Pemoderasi Terhadap Penghindaran Pajak .Skripsi. Fakultas Ekonomi dan Bisnis Universitas Syarif Hidayatullah : Jakarta.

Lin, We-Yi., Liu, Y.A., dan Keng, I. (2016). Related Party Transaction, Firm Performance and Control Mechanisms: Evidence From Taiwan. Journal of Finance and Economics.

Mardiasmo. (2016). Perpajakan. Yogyakarta : Andi.

Masri, Indah, dan Martani, Dwi. (2012). Pengaruh Tax Avoidance terhadap Cost of Debt. Simposium Nasional Akuntansi XV : Banjarmasin

Neolaka, Amos. (2014). Metode Penelitian dan Statistik. Remaja Rosdakarya : Bandung.

Nuraini, N.S dan Marsono. (2014). Analisis Faktor-Faktor yang Mempengaruhi Thin Capitalization pada Perusahaan Multinasional di Indonesia. Diponegoro Journal of Accounting 3(3) : 1-9.

Oktavia, Septian Bayu Kristianto, Subagyo dan Herni Kurniawati. (2012). Transaksi Hubungan Istimewa dan Pengaruhnya Terhadap Tarif Pajak Efektif Perusahaan. Jurnal Akuntansi, Vol. 12, No. 2, Nov. 2012: 701-716.

Peraturan Direktur Jenderal Pajak Nomor PER-43/PJ/2010 tentang Penerapan Prinsip Kewajaran dan Kelaziman Usaha dalam Transaksi antara Wajib Pajak dengan Pihak yang Mempunyai Hubungan Istimewa.

Peraturan Menteri Keuangan Republik Indonesia Nomor 169/PMK.010/2015 tentang "Penentuan Besarnya Perbandingan Antara Utang dan Modal Perusahaan untuk Keperluan Penghitungan Pajak Penghasilan.

Peraturan Undang-Undang Pajak Penghasilan Pasal 18 No. 36 Tahun 2008 (Undang-Undang PPh) tentang Hubungan Istimewa.

Priyanto, Duwi., 2010. Mandiri Belajar Analisis Data Dengan SPSS.MediaKom : Yogyakarta.

Pea, Fransiskus A. (2017). Pengaruh Ukuran Perusahaan, Leverage dan Pertumbuhan Penjualan Terhadap Tax Avoidance. Skripsi. Fakultas Ekonomi dan Bisnis Universitas Pasundan : Bandung.

Rizali, Ananda D. (2017). Pengaruh Related Party Transaction Terhadap Nilai Perusahaan Sebagai Variabel Intervening.

Santoso, Singgih. (2015). Menguasai SPSS 22. PT Elex Media Komputindo : Jakarta.

Sugiyono. (2016). Metode Penelitian Pendidikan Pendekatan Kuantitatif, Kualitatif, dan $R \& D$. Alfabeta : Bandung.

Sunarto. (2009). Teori Keagenan dan Manajemen Laba. Kajian Akuntansi. ISSN:1979-4886.

Sunyoto, Danang. (2007). Metodologi Penelitian Akuntansi, cetakan kesatu, PT Refika Aditama : Bandung. 
Tiwa, Evan M, Saerang, David P.E, Tirayoh, Victorina Z. (2017). Pengaruh Pajak dan Kepemilikan Asing Terhadap Penerapan Transfer Pricing pada Perusahaan Manufaktur yang Terdaftar di BEI tahun 2013-2015. Jurnal EMBA Vol. 5 No. 2.

Undang-Undang No. 36 Tahun 2008 Tentang Pajak Pengahasilan.

Undang-Undang No. 16 tentang perubahan keempat atas Undang-Undang No. 6 Tahun 1983 tentang Ketentuan Umum dan Tata Cara Perpajakan.

Yuliati, Rina. (2016). Pengaruh Transaksi Transfer Pricing dan Thin Capitalization Terhadap Praktik Penghindaran Pajak. Skripsi, Fakultas Ekonomi Universitas Pamulang.

https://www.finansialku.com/mengenal-sejarah-bursa-efek-indonesia-idx/) www.kemenkeu.go.id/APBN2017 